\title{
Epithelial-Mesenchymal Transition in Head and Neck Cancer
}

\author{
Gi Cheol Park \\ Department of Otorhinolaryngology-Head and Neck Surgery, Samsung Changwon Hospital, \\ Sungkyunkwan University School of Medicine, Changwon, Korea \\ 두경부암에서의 상피-간엽이행 \\ 박기철 \\ 성균관대학교 의과대학 삼성창원병원 이비인후과학교실
}

Received June 3,2020

Revised July 16,2020

Accepted July 23, 2020

Address for correspondence

Gi Cheol Park, MD, PhD

Department of Otorhinolaryngology-

Head and Neck Surgery,

Samsung Changwon Hospital,

Sungkyunkwan University

School of Medicine,

158 Paryong-ro, MasanHoewon-gu, Changwon 51353, Korea

Tel $+82-55-233-5983$

Fax $+82-55-233-5441$

E-mail uuhent@gmail.com
Metastasis is one of the most important factors in the prognosis and choice of treatment strategy of patients with head and neck squamous cell carcinoma (HNSCC). In order for dissemination to take effect, tumor cells must segregate themselves from their primary tumor site and migrate into the blood or lymphatic vessels. To detach from the primary tumor, cells have to disrupt cell-cell adhesion, remodel of the cytoskeleton, change in cell-matrix adhesion and finally return to their original condition. This temporary and reversible process is known as the epithelial-mesenchymal transition (EMT). EMT is a dynamic cellular process in which epithelial cells acquire mesenchymal features and suggested to play an important role during cancer invasion and metastasis. With the recent explosion of knowledge on EMT in carcinogenesis, EMT has become an interesting target for anticancer therapy. This review article first highlights at the biochemical changes that take place around the cell membrane called cadherin switching during EMT and looks at the current literature on EMT in HNSCC. Understanding the mechanism of EMT will provide insight to the metastasis of HNSCC and may lead to the development of novel anti-cancer therapeutics.

Korean J Otorhinolaryngol-Head Neck Surg 2020;63(9):397-402

Key Words Cadherin switching · Epithelial-mesenchymal transition · Head and neck cancer $\cdot$ Metastasis.

\section{서 론}

두경부암은 전 세계에서 매년 40만 명에서 60만 명 정도가 새로이 발생하고, 30 만 명 가까이 사망하는 6번째로 흔한 암 이다. ${ }^{1)}$ 30 40\%의 환자들은 초기 단계에서 진단이 되어 70 $90 \%$ 의 5년 생존율을 보이나, 나머지의 환자들은 진행된 단계 에서 진단이 되며 적절한 치료에도 불구하고 생존율은 30 $40 \%$ 로 떨어지게 된다. ${ }^{23)}$ 구강, 인두, 후두, 경부 등 다양한 부

This is an Open Access article distributed under the terms of the Creative Commons Attribution Non-Commercial License (https://creativecommons.org/licenses/by-nc/4.0) which permits unrestricted non-commercial use, distribution, and reproduction in any medium, provided the original work is properly cited.
위에서 발생하는 두경부암의 특성상 부위에 따른 차이는 있 겠지만 림프절 전이는 모든 두경부암의 치료 성적에 가장 큰 영향을 미치는 예후 인자이다. 림프절 전이가 있는 경우에는 그렇지 않은 경우에 비해 예후가 절반으로 감소하며, 특히 피 막 외 침범이 있는 림프절 전이가 있으면 생존율이 10 25\% 까지 떨어지게 된다. ${ }^{3-6)}$ 또한 경부 림프절 전이는 향후 경부 이외 부위로의 원격전이의 발판이 될 수도 있다.'

암세포가 림프관을 타고 전이를 하기 위해서는 세포의 이 동이 필요하다. 암세포가 이동하기 위해서는 원발 부위에서 떨어져 나와서 기질로 침습하여 혈관이나 림프관에 들어가야 한다. 안정적으로 세포군락을 이루던 상태에서 다른 세포와 
떨어져 이동을 하기 위해서는 세포의 특성들이 바뀌어야 하 는데 이러한 과정을 상피-간엽이행(epithelial-mesenchymal transition, EMT)이라 한다. ${ }^{8-10)}$ 상피세포는 정방형 모양으로 위쪽과 기저쪽이 확실히 구분되는 극성을 띄며 세포간 접촉 을 유지하려는 특성을 가지고 있다. 이에 반해 간엽세포는 세 포의 모양이 섬유아세포형으로 극성이 사라지고 다른 세포와 의 접촉 없이 이동과 침윤이 용이하게 된다. 상피-간엽이행은 안정적인 세포간 결합을 이루고 있던 상피형 세포가 이동에 편한 간엽형 세포로 변화하는 복잡하고 가역적인 과정으로 종양의 생성, 악성화 과정, 암줄기세포, 암세포의 이동, 전이, 치료에 대한 저항성 등 암세포의 다양한 과정에 모두 연관되 어 있는 것으로 알려져 있다(Fig. 1). ${ }^{11-15)}$ 두경부종양에서도 다른 기관의 암에 비해서는 부족하지만 상피-간엽이행과 관 련된 연구들이 진행되고 있다. ${ }^{16,17)}$ 하지만 두경부암을 포함한 대부분의 연구들은 상피-간엽이행이 일어나기 전과 후의 상 태를 나타내는 표지자들의 발현량을 비교하는 것이 주를 이 루며, 암세포에서 상피-간엽이행이 일어나는 과정에 대한 연 구는 아직 미비한 상태이다. 암의 진행과 전이에 대한 이해 및 추후 치료적 접근을 위해서는 암세포에서 일어나는 상피-간 엽이행의 과정에 대한 명확한 이해가 필수적이다.

이번 종설에서는 암세포에서 상피-간엽이행이 일어나는 과 정 중에 세포 내에서 일어나는 변화들에 대해 현재까지 알려 진 내용들을 중심으로 알아보고 두경부암에서 상피-간엽이 행과 관련된 임상연구들을 간단히 살펴보고자 한다.

\section{상피-간엽이행과 카데린}

상피세포들의 세포간 결합 중 부착연접(adhering junction) 에는 카데린(cadherin)이라는 세포부착분자(adhesion molecule)가 인접한 두 세포를 연결해 준다. ${ }^{18)}$ 카데린은 세포막을 관통하여 위치하는 수용체 단백질로 5개의 세포외구역(extracellular domain)을 가지며, 인접세포에 위치한 다른 카데 린과 결합하여 세포간의 단단한 결합의 유지시킨다. 카데린의 세포내구역(intracellular domain)은 $\alpha-, \beta-$ 카테닌과 결합하 여 세포의 전반적인 골격을 형성하는 액틴과 연결된다. 카데 린에 의한 세포간 결합은 세포군락을 이루기 위해 필수적이 며 부착연접 뿐아니라 밀착연접(tight junction)과 같은 다른 세포결합의 형성과 붕괴에도 영향을 미치게 된다. 또한 세포 내외를 관통하는 구조적인 특성상 인근세포로부터 전해지는 물리화학적인 신호를 세포 내로 전달하기도 한다. 카데린의 종류는 100 여 가지 이상이 있으나 가장 기본적으로 E-카데 린과 $\mathrm{N}-$ 카데린이 있으며 이 둘은 구조적으로 매우 비슷하 다. ${ }^{19)}$ 둘 다 세포간 결합에 의해 전달되는 물리적 힘의 정도에 따라 세포외구역의 형태가 달라지고 이는 화학적 신호로 변 환되어 세포 내에 전달된다. E-카데린은 대부분의 정상적인 상피세포에서 발현된다. N-카데린은 세포의 이동이 비교적 활발한 신경세포나 간엽세포들에서 잘 발현된다. 단백질의 골격도 비슷하고 세포막에서의 역할도 비슷하지만 암세포에 서는 그 기능이 극명하게 차이가 난다(Fig. 2). ${ }^{20,21)}$

암세포가 안정적으로 세포간의 접촉을 잘 이루고 있을때는

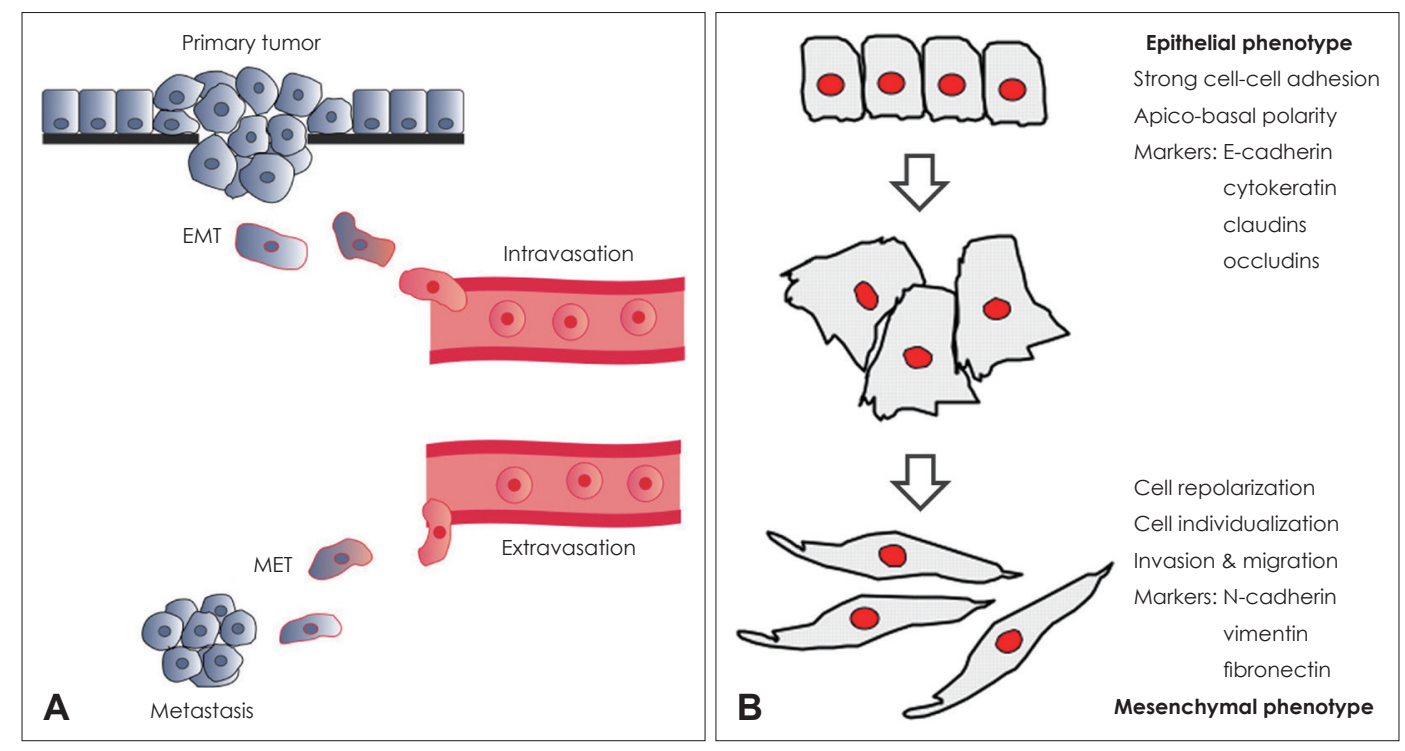

Fig. 1. Metastasis and EMT. To detach from the primary tumor andinvade into distant tissue, tumor cells have to break down cell-cell contacts, change shape, move and finally return to their original condition. This temporary and reversible process is known as the EMT (A). EMT allows a functional transition of polarized epithelial cells into mobile mesenchymal cells which enhances migratory capacity, invasiveness (B). EMT: epithelial-mesenchymal transition, MET: mesenchymal-epithelial transition. Adapted from: Samatov TR. et al. Mol Cancer 2013;12:107.39) 


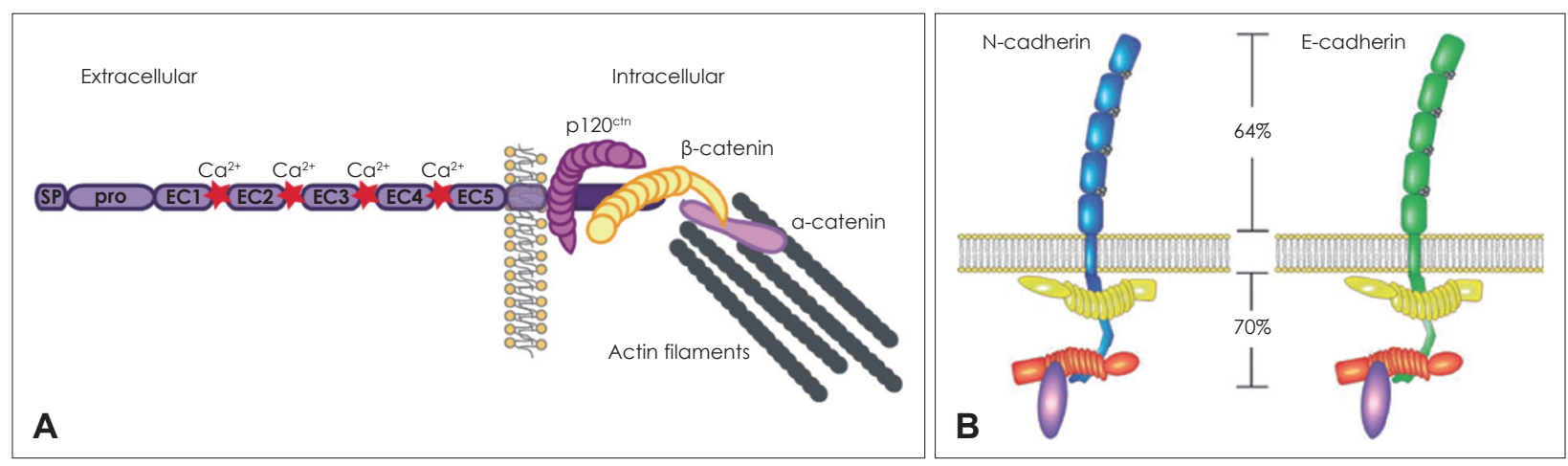

Fig. 2. Structure of cadherin. Cadherins have 5 extracellular domain, and $C$-terminal portion of the cytoplasmic domain binds to $\beta$-catenin, which binds to $\alpha$-catenin. P120-catenin binds to the juxtamembrane domain (A). Percentages indicate sequence identify between E-and $\mathrm{N}$-cadherin (B). Adapted from: Wheelock MJ, et al. J Cell Sci 2008;121:727-35. ${ }^{18}$ and Stemmler MP. Mol Biosyst 2008;4:835-50. ${ }^{19}$

세포막에 E-카데린이 주로 존재한다. E-카데린은 주변 세포 의 E-카데린과 연결되여 안정된 결합 상태를 만들고 세포를 상피표현형으로 유지시킨다. 세포간 결합 부위에 외부로부터 의 물리화학적인 자극이 발생하면 상피-간엽이행이 시작되고 세포간 접촉부위의 수용체 단백질들의 분포가 변화하기 시 작한다. 제일 먼저 시작되는 변화는 여러가지 경로를 통해 기 존에 세포막에 존재하던 $\mathrm{E}-$ 카데린들이 분해되고 새로 만들 어지지 않는 것이다. $\mathrm{E}-$ 카데린이 감소하게 되는 과정은 크게 전사조절(transcriptional control)과 그 후 과정으로 나눌 수 있다. 상피-간엽이행이 시작하게 되면 Snail, Slug, ZEB1, ZEB2, E47, Twist 등의 다양한 전사인자들이 TGF- $\beta, \mathrm{HGF}$, $\mathrm{EGF}, \mathrm{Wnt}$, Notch 등의 경로를 통해 핵내에서 E-카데린의 전사를 억제하게 된다. 이처럼 핵 내부에서 새로운 $\mathrm{E}-$ 카데린 의 생성을 억제하는 동안 세포막에서는 기존에 만들어져 세 포간 결합을 이루고 있는 $\mathrm{E}-$-카데린의 붕괴가 동시에 진행된 다. 상피-간엽이행이 시작되면 $\mathrm{Src}$ 나 FAK 등에 의해 E-카 데린의 세포내구역이 인산화되게 되고, 이어서 주변에 있던 E3-ubiquitin-ligase Hakai, $\gamma$-secretase 등에 의해 붕괴되 어 정상적인 기능을 소실하게 된다. $\mathrm{E}-$ 카데린에 붙어있던 $\beta-$ 카테닌도 인산화되면서 $\mathrm{E}-$ 카데린과 떨어진 후 일부는 핵내 부로 진입하여 $\mathrm{E}-$ 카데린의 생성을 억제하게 된다.

한편 $\mathrm{E}^{-}$카데린에는 액틴과 연결시켜주는 $\alpha^{-}, \beta-$-카테닌 외 에 p120-카테닌도 연결되어 있다. P120-카테닌은 액틴의 재 합성 과정을 조절하여 세포의 형태를 바꾸고 세포 이동에 중 요한 역할을 하는 Roh GTPase의 활성화를 조절하여 카데 린-카테닌-액틴 조합을 안정화하는 역할을 한다. E-카데린 의 세포내구역에 $\mathrm{p} 120$-카테닌이 안정적으로 붙어있을 때는 $\mathrm{E}-$ 카데린의 기능이 정상적으로 유지되지만, $\mathrm{E}-$ 카데린에서 $\mathrm{p} 120$-카테닌이 떨어져 나오게 되면 E-카데린을 중심으로하 는 카테닌-액틴 연결이 끊어지게 된다.

\section{카데린 전환(Cadherin Switching)}

부착연접에서 큰 비중을 차지하며 세포간 연결에 중요한 역할을 하던 $\mathrm{E}-$ 카데린이 감소하게 된 후 발생하는 세포막의 빈 공간은 $\mathrm{N}-$ 카데린으로 채워지게 된다. $\mathrm{E}-$ 카데린과 구조적 으로 거의 비슷한 형태를 가진 $\mathrm{N}$-카데린은 부착연접 내 맞 은편 세포에 있는 N-카데린과 결합하고 세포 내부에서는 $\alpha^{-}$, $\beta$-카테닌을 통해 액틴과 연결되어 있다. E-카데린에서 떨어 져 나와 세포질에 떠돌던 P120-카테닌 역시 N-카데린과 결 합하여 N-카데린을 중심으로하는 카테닌-액틴 연결을 더욱 공고하게 유지시키게 된다. 이러한 경로를 통해 안정적인 상 태의 세포막 주로 분포하던 $\mathrm{E}-$ 카데린이 감소하고 그 자리에 $\mathrm{N}-$ 카데린이 증가하게 되는 과정을 카데린 전환(cadherin switching)이라 한다. 카데린 전환은 상피-간엽이행 과정 중 가장 특징적이며 중요한 변화이다. ${ }^{18,22)}$

RhoA, Rac1, Cdc42는 Ras-related GTP-binding protein 으로 세포 외부로부터의 자극에 대한 반응으로 액틴에 의한 세포골격의 합성과 분해를 조절하는 역할을 한다. 상피-간엽 이행이 일어나는 동안 액틴의 재배열을 조절하여 세포의 모 양을 변형시키고 세포이동이 일어날 수 있도록 한다. RohA는 actin stress fiber를 강화시켜서 세포간 결합을 안정화한다. 이에 반해 Cdc42와 Rac1은 branch-like actin protrusion을 만들어 세포의 무게중심을 이동시켜 세포간 결합을 약화시키 며 특히 Racl은 RhoA에 대해 길항적으로 작용한다. 세포막 주변에 RhoA가 활성화되어 있는 상태에는 세포의 현재 상태 가 강하게 유지되는 경향이 있는 반면 Rac1이 활성화 되면 그 주위로 액틴섬유들의 모양이 변화하면서 lamellipodia가 형 성이 되고 세포의 모양이 변하게 된다.

카데린 전환이 일어나 세포연접부위가 $\mathrm{E}$-카데린에서 $\mathrm{N}-$ 카 데린으로 바뀌게 되면 Rac1의 분포도 바뀌게 된다. Rac1은 세포연접에 $\mathrm{E}-$ 카데린이 많이 존재하며 안정적으로 결합이 유 
지되고 있을 때는 $\mathrm{E}-$ 카데린 근처에 많이 분포하다가 카데린 전환이 일어나 $\mathrm{N}$-카데린으로 바뀌게 되면 세포연접 부위로 부터 멀어지게 된다. Rac1이 연접부위가 없는 다른쪽으로 이 동하게 되면 그 부위를 중심으로 액틴에 의한 세포골격이 재 형성되게 되고 세포의 무게중심이 세포연접부위에서 다른 곳 으로 옮겨지게 된다. 세포 내의 물리적 긴장의 위치가 변하게 되면서 $\mathrm{N}-$ 카데린에 의해 연결되어있던 세포결합이 붕괴되면 서 세포의 이동이 시작된다. ${ }^{23)} \mathrm{Rac} 1$ 이 $\mathrm{E}$-카데린이 있을 때는 세포연접부위 근처에 있다가 N-카데린으로 바뀌자 반대편 으로 이동하게 되는 과정에 대해서는 아직 밝혀지지 않았다.

\section{두경부암에서의 상피-간엽이행}

두경부암에서 상피-간엽이행과 관련된 연구들은 다른 암 에 비해 활발하게 이루어지고 있지는 않은 상태이며, 조직이 나 혈액에서 상피-간엽이행과 연관된 biomarker의 발현을 조사하여 두경부암에서의 상피-간엽이행의 역할을 규명하는 연구가 간간히 있어온 정도이다. 연관되는 biomarker로는 간 엽형 세포에서 발현되는 vimentin, N-cadherin, fibronectin 과 상피형 세포에서 발현되는 E-cadherin, cytokeratin 등이 있으며, 상피-간엽이행의 전사인자인 Snail, Slug, Twist, ZEB1, ZEB2 등이 있다.

80명의 두경부 환자를 대상으로 한 상피-간엽이행 연구를 보면 N-카데린이 높게 발현한 52명의 환자의 예후가 유의하 게 안좋은 것으로 나타났으며, 카데린 전환이 일어난 것으로 판정된 30명의 환자들의 조직을 분석한 결과 세포의 침윤도 나 임파선 전이가 유의하게 더 높게 나왔다. 또한 두경부암 세포주에서 카데린 전환이 일어난 세포들의 표현형이 간엽형 세포로 변한 것도 확인하였다. ${ }^{24}$ 26명의 두경부암 환자를 대 상으로 한 다른 연구에서도 $\mathrm{E}$-카데린이 낮게 검출되고 $\mathrm{vi}^{-}$ mentin이 높게 검출되는 환자들은 그렇지 않은 환자들에 비 해 2 배 이상 높은 전이율을 보였다. ${ }^{25}$ 상피-간엽이행의 전사 인자인 Slug 발현이 침샘에서 발생한 선양낭성암의 재발과 전이에도 관련이 있다는 연구도 있으며, ${ }^{26)}$ 특히 Slug는 두경 부암세포의 단독이동이 아닌 세포군락의 집단이동에 관여한 다고 보고된다. ${ }^{27)}$ 상피-간엽이행을 일으키는 인자로서 가장 널리 알려져있는 TGF 1 은 두경부암에서도 높게 검출되었으 며, 두경부암세포주에서도 TGF 1 1가 Slug뿐만 아니라 다양 한 경로를 통하여 세포의 표현형을 바꾸고 상피-간엽이행을 일으키는 것을 확인하였다. ${ }^{28,29)}$ 또한, EGFR과 VEGFR, Wnt 등의 다른 성장인자들도 두경부암세포의 상피-간엽이행에 관여하는 것으로 보고된다. ${ }^{30,31)}$ 저산소증(hypoxia)도 두경부 암의 상피-간엽이행과 관련이 있다. HIF- $1 \alpha$ 가 여러 독립적인
기전을 통해 저산소증에 의해 유발되는 상피-간엽이행을 조 절한다. ${ }^{32,33)}$ 구인두암의 중요한 인자인 인체유두종바이러스 감염은 상피-간엽이행과 관련이 없는 것으로 보고된다. 296명 의 구인두암 환자들을 대상으로 한 연구에서 인체유두종바 이러스 감염은 E-카데린과 vimentin의 발현과 큰 연관성이 없었다. ${ }^{34)}$

\section{결 론}

현재까지 상피-간엽이행을 유도하는 인자들에 대한 연구나 상피-간엽이행이 일어난 후의 변화된 세포의 특징들에 대해 서는 많은 연구가 되어있지만 상피-간엽이행이 일어나는 과 정 자체에 대한 연구, 특히 세포막에서의 카데린 전환 과정에 대한 이해는 여전히 부족하다. 특히 E-카데린과 비슷한 구조 이지만 완전히 다른 역할을 하는 N-카데린에 대해서는 연구 가 거의 이루어지지 않았다. 상피-간엽이행 중 N-카데린이 세포간연접부위에 발현하게 되면 세포접촉이 붕괴되고 반대 쪽으로 세포의 재분극이 일어나게 되는 일련의 과정에 대해 서는 아직 자세히 모르는 상태이다. 상피-간엽이행에서 필수 적인 카데린 전환의 과정에 대한 이해가 부족한 이유는 살아 있는 세포에서 카데린을 제어하면서 세포막 주변 분자들의 변화를 관찰하것을 실험적으로 구현하기 어렵기 때문이다. 다행히 최근에 나노프로브 시스템을 이용하여 살아있는 세 포에서 카데린이나 notch 같은 세포막수용체 단백질들을 조 절하면서 세포막 주변의 신호전달 과정을 높은 해상도로 영 상화할 수 있는 기술들이 개발되어 이에 대한 연구들이 시작 되고 있다. ${ }^{35-38)}$ 카데린 전환 과정과 그후에 일어나는 세포 내 의 변화에 기전이 밝혀진다면 이를 이용한 치료제의 개발이 활발히 이루어 질 것이다.

\section{Acknowledgments}

This work was supported by the National Research Foundation of Korea (NRF) grant funded by the Korea government (MSIT) (No. NRF-2020R1F1A1064763 to Gicheol Park).

\section{ORCID}

Gi Cheol Park https://orcid.org/0000-0001-7346-8550

\section{REFERENCES}

1) Chaturvedi AK, Anderson WF, Lortet-Tieulent J, Curado MP, Ferlay J, Franceschi S, et al. Worldwide trends in incidence rates for oral cavity and oropharyngeal cancers. J Clin Oncol 2013;31(36): $4550-9$.

2) Hashim D, Genden E, Posner M, Hashibe M, Boffetta P. Head and neck cancer prevention: From primary prevention to impact of clinicians on reducing burden. Ann Oncol 2019;30(5):744-56.

3) Attar E, Dey S, Hablas A, Seifeldin IA, Ramadan M, Rozek LS, et al. Head and neck cancer in a developing country: A population- 
based perspective across 8 years. Oral Oncol 2010;46(8):591-6.

4) Puri SK, Fan CY, Hanna E. Significance of extracapsular lymph node metastases in patients with head and neck squamous cell carcinoma. Curr Opin Otolaryngol Head Neck Surg 2003;11(2): $119-23$.

5) Martinez-Useros J, Garcia-Foncillas J. The challenge of blocking a wider family members of EGFR against head and neck squamous cell carcinomas. Oral Oncol 2015;51(5):423-30.

6) Polesel J, Furlan C, Birri S, Giacomarra V, Vaccher E, Grando G, et al. The impact of time to treatment initiation on survival from head and neck cancer in north-eastern Italy. Oral Oncol 2017;67: 175-82.

7) Cho JK, Hyun SH, Choi N, Kim MJ, Padera TP, Choi JY, et al. Significance of lymph node metastasis in cancer dissemination of head and neck cancer. Transl Oncol 2015;8(2):119-25.

8) Zeisberg M, Neilson EG. Biomarkers for epithelial-mesenchymal transitions. J Clin Invest 2009;119(6):1429-37.

9) Zhang Y, Weinberg RA. Epithelial-to-mesenchymal transition in cancer: Complexity and opportunities. Front Med 2018;12(4):36173.

10) Lamouille S, Xu J, Derynck R. Molecular mechanisms of epithelialmesenchymal transition. Nat Rev Mol Cell Biol 2014;15(3):178-96.

11) Shibue T, Weinberg RA. EMT, CSCs, and drug resistance: The mechanistic link and clinical implications. Nat Rev Clin Oncol 2017;14(10):611-29.

12) Mani SA, Guo W, Liao MJ, Eaton EN, Ayyanan A, Zhou AY, et al. The epithelial-mesenchymal transition generates cells with properties of stem cells. Cell 2008;133(4):704-15.

13) Ye X, Tam WL, Shibue T, Kaygusuz Y, Reinhardt F, Ng Eaton E, et al. Distinct EMT programs control normal mammary stem cells and tumour-initiating cells. Nature 2015;525(7568):256-60.

14) Thiery JP, Acloque H, Huang RY, Nieto MA. Epithelial-mesenchymal transitions in development and disease. Cell 2009;139(5):871-90.

15) Peinado H, Olmeda D, Cano A. Snail, Zeb and bHLH factors in tumour progression: An alliance against the epithelial phenotype? Nat Rev Cancer 2007;7(6):415-28.

16) Chung CH, Parker JS, Ely K, Carter J, Yi Y, Murphy BA, et al. Gene expression profiles identify epithelial-to-mesenchymal transition and activation of nuclear factor-kappaB signaling as characteristics of a high-risk head and neck squamous cell carcinoma. Cancer Res 2006;66(16):8210-8.

17) Smith A, Teknos TN, Pan Q. Epithelial to mesenchymal transition in head and neck squamous cell carcinoma. Oral Oncol 2013;49(4): 287-92.

18) Wheelock MJ, Shintani Y, Maeda M, Fukumoto Y, Johnson KR. Cadherin switching. J Cell Sci 2008;121(Pt 6):727-35.

19) Stemmler MP. Cadherins in development and cancer. Mol Biosyst 2008;4(8):835-50.

20) Sabatini PJ, Zhang M, Silverman-Gavrila R, Bendeck MP, Langille BL. Homotypic and endothelial cell adhesions via N-cadherin determine polarity and regulate migration of vascular smooth muscle cells. Circ Res 2008;103(4):405-12.

21) Giampietro C, Taddei A, Corada M, Sarra-Ferraris GM, Alcalay M, Cavallaro U, et al. Overlapping and divergent signaling pathways of N-cadherin and VE-cadherin in endothelial cells. Blood 2012; 119(9):2159-70.

22) Maeda M, Johnson KR, Wheelock MJ. Cadherin switching: Essential for behavioral but not morphological changes during an epithelium-to-mesenchyme transition. J Cell Sci 2005;118(Pt 5): 873-87.

23) Scarpa E, Szabó A, Bibonne A, Theveneau E, Parsons M, Mayor R.
Cadherin switch during EMT in neural crest cells leads to contact inhibition of locomotion via repolarization of forces. Dev Cell 2015; 34(4):421-34

24) Nguyen PT, Kudo Y, Yoshida M, Kamata N, Ogawa I, Takata T. $\mathrm{N}$-cadherin expression is involved in malignant behavior of head and neck cancer in relation to epithelial-mesenchymal transition. Histol Histopathol 2011;26(2):147-56.

25) Nijkamp MM, Span PN, Hoogsteen IJ, van der Kogel AJ, Kaanders $\mathrm{JH}$, Bussink J. Expression of E-cadherin and vimentin correlates with metastasis formation in head and neck squamous cell carcinoma patients. Radiother Oncol 2011;99(3):344-8.

26) Tang Y, Liang $X$, Zheng M, Zhu Z, Zhu G, Yang J, et al. Expression of c-kit and Slug correlates with invasion and metastasis of salivary adenoid cystic carcinoma. Oral Oncol 2010;46(4):311-6.

27) Jouppila-Mättö A, Närkiö-Mäkelä $M$, Soini $Y$, Pukkila $M$, Sironen $\mathrm{R}$, Tuhkanen $\mathrm{H}$, et al. Twist and Snail expression in pharyngeal squamous cell carcinoma stroma is related to cancer progression. BMC Cancer 2011;11:350.

28) Qiao B, Johnson NW, Gao J. Epithelial-mesenchymal transition in oral squamous cell carcinoma triggered by transforming growth factor-beta1 is Snail family-dependent and correlates with matrix metalloproteinase-2 and -9 expressions. Int J Oncol 2010;37(3):663-8.

29) Joseph MJ, Dangi-Garimella S, Shields MA, Diamond ME, Sun L, Koblinski JE, et al. Slug is a downstream mediator of transforming growth factor-betal-induced matrix metalloproteinase-9 expression and invasion of oral cancer cells. J Cell Biochem 2009;108(3):72636.

30) Richter P, Umbreit C, Franz M, Berndt A, Grimm S, Uecker A, et al. EGF/TGF $\beta 1$ co-stimulation of oral squamous cell carcinoma cells causes an epithelial-mesenchymal transition cell phenotype expressing laminin 332. J Oral Pathol Med 2011;40(1):46-54.

31) Thiery JP. Epithelial-mesenchymal transitions in tumour progression. Nat Rev Cancer 2002;2(6):442-54.

32) Yang MH, Hsu DS, Wang HW, Wang HJ, Lan HY, Yang WH, et al. Bmil is essential in Twist1-induced epithelial-mesenchymal transition. Nat Cell Biol 2010;12(10):982-92.

33) Huang CH, Yang WH, Chang SY, Tai SK, Tzeng CH, Kao JY, et al. Regulation of membrane-type 4 matrix metalloproteinase by SLUG contributes to hypoxia-mediated metastasis. Neoplasia 2009;11(12):1371-82.

34) Lefevre M, Rousseau A, Rayon T, Dalstein V, Clavel C, Beby-Defaux A, et al. Epithelial to mesenchymal transition and HPV infection in squamous cell oropharyngeal carcinomas: The papillophar study. Br J Cancer 2017;116(3):362-9.

35) Kim JW, Jeong HK, Southard KM, Jun YW, Cheon J. Magnetic nanotweezers for interrogating biological processes in space and time. Acc Chem Res 2018;51(4):839-49.

36) Kim JW, Seo D, Lee JU, Southard KM, Lim Y, Kim D, et al. Single-cell mechanogenetics using monovalent magnetoplasmonic nanoparticles. Nat Protoc 2017;12(9):1871-89.

37) Kwak M, Gu W, Jeong H, Lee H, Lee JU, An M, et al. Small, clickable, and monovalent magnetofluorescent nanoparticles enable mechanogenetic regulation of receptors in a crowded live-cell microenvironment. Nano Lett 2019;19(6):3761-9.

38) Seo D, Southard KM, Kim JW, Lee HJ, Farlow J, Lee JU, et al. A mechanogenetic toolkit for interrogating cell signaling in space and time. Cell 2017;169(7):1357.

39) Samatov TR, Tonevitsky AG, Schumacher U. Epithelial-mesenchymal transition: Focus on metastatic cascade, alternative splicing, noncoding RNAs and modulating compounds. Mol Cancer 2013;12(1): 107. 


\section{정답 및 해설}

답 (5)

해 설 (1) T3b: 원발종양 크기와 상관없이 피대근(흉골설골근, 흉골갑상근, 갑상설골근, 견갑설골근)에 국한한 육안적 갑상선외 침 범이 있는 경우.

(2), (3), (4), (5) 2015년 미국 갑상선 학회(American Thyroid Association)에서 제시한 갑상선 결절과 분화암의 치료 권고안에 따르면 갑상선 암이 $4 \mathrm{~cm}$ 보다 크거나, 거시적인 갑상선 피막 외 침범이 관찰되거나, 림프절전이나 타 장기로의 원격전이가

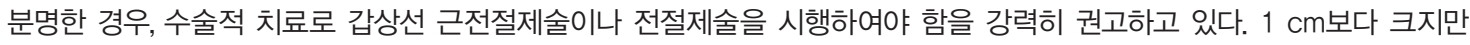
$4 \mathrm{~cm}$ 보다 작은 갑상선암의 경우, 갑상선 피막외 침범과 암종의 전이가 임상적으로 없는 경우에는 양측 갑상선을 모두 절제 하는 수술이나 암종이 있는 일측의 갑상선을 절제하는 수술 중 어느 것을 선택하여도 무방하다. 또한 주변 림프절 전이나 갑상선 피막 외 침범의 증거가 없는 $1 \mathrm{~cm}$ 미만의 갑상선 분화암종에 대한 치료로는 갑상선엽 절제술을 시행할 것을 권고하 고 있다.

참고 문헌: 대한이비인후과학회. 이비인후과학:두경부. 파주: 군자출판사;2018. p.820, 841-2. 